\title{
Towards an Efficient Integrated Distance and Blended Learning Model: How to Minimise the Impact of COVID- 19 on Education
}

\author{
https://doi.org/10.3991/ijim.v15i10.21331 \\ Ahmed Al-Hunaiyyan $\left.{ }^{(}\right)$, Rana Alhajri \\ Public Authority for Applied Education and Training, Adailiyah, Kuwait \\ aa.alhunaiyyan@paaet.edu.kw \\ Andrew Bimba \\ University Malaya, Kuala Lumpur, Malaysia
}

\begin{abstract}
As governments and international bodies worldwide sought to prevent the spread of Covid-19, underdeveloped countries have been particularly challenged as they have little or no technological models and frameworks in place and the literature offers little guidance. The current research applied a quantitative approach to researching educational practitioners' perceptions of elearning acceptance, using a sample of 4,024 educators and students from a range of Kuwaiti educational institutions. Findings indicate that respondents were slightly supportive of e-learning adoption, with a majority acknowledging its advantages. However, respondents also mention the need for development in the technological competencies required to operate the proposed e-learning programs and a range of challenges that may impact e-learning. Hence, the authors propose a distance and blended learning model (DBLM) to enhance the implementation, utilisation, and evaluation of e-learning within the Kuwaiti educational system. Also, an e-learning teacher capability maturity model (eTCMM) was proposed to foster educators' competencies and enable their active use of elearning platforms.
\end{abstract}

Keywords-Distance learning, Covid-19 Pandemic, e-learning, Perceptions, Modeling, competency

\section{Introduction}

When natural or human-made catastrophes occur, such as pandemics, floods, earthquakes, wars and political disturbances, their impact is felt across multiple areas, such as economies, health, and education. As Covid-19 spread rapidly across borders, governments worldwide began restricting the size of public gatherings, with immediate consequences for the normal functioning of schools and universities. By late April, schools had been shut in 186 countries, affecting more than 1.2 billion students [1]. In this context, educators everywhere have been forced to find innovative ways to ensure 
their students continue to receive an education. In many places, distance learning became mandatory for the remainder of the academic year [2].

Distance learning is currently delivered in a range of formats, including standalone and virtual-classroom courses, learning simulations, embedded e-learning; and blended or mobile learning [3]. There are three principal modes of distance learning, according to Ref. [4]. The first is fully-fledged online, or distance learning, whereby all educational content is provided online. Learning Management Systems (LMSs) are fundamental to this mode as they provide collaborative tools which allow educatorstudent communication [5]. The second mode consists of standalone e-courses, during which students, rather than instructors, set the pace at which they learn. The third mode consists of blended learning, in which e-learning tools are integrated within a traditional classroom environment but can be accessed remotely, 24/7, via an LMS or internet connection.

Many educational institutions have been able to adopt distance learning; indeed, in many countries, doing so became obligatory as one of many measures taken to control the spread of the Covid-19 virus. However, disquiet has been expressed by experts, educators, and students about the consequences, with some providers unsure whether the quality or content of curricula would be compromised by the transfer from traditional to online teaching methods [6]. The State of Kuwait is classified as a developing country. Hence, information and communication technologies (ICT) and associated e-learning practices were not in widespread use before the onset of the pandemic. Instead, the educational system was characterised by traditional, face-to-face delivery of content within a classroom environment. Several attempts had been made to introduce online learning, but the majority were unsuccessful. According to Ref. [7], Kuwait lags behind other nations, despite its high living standards, due to its low rate of innovation and failure to nurture and sustain capabilities. When the Kuwaiti authorities responded decisively to the Covid-19 pandemic by closing educational institutions from March 1, 2020, educational authorities were obliged to consider how best to ensure learning continuity. One option was the switch to online delivery; however, although this was a good strategy for controlling the spread of the virus, the measure had both supporters and opponents.

Therefore, this research seeks to understand the critical factors behind the acceptance and adoption of e-learning in Kuwait during the Covid-19 pandemic; secondly, to identify, from educators and students' perspective, the opportunities and challenges inherent in diverse technology-based learning paradigms. Hence, the following research questions have been formulated:

1. What are instructors' and students' perceptions of online and distance learning adoption to maintain learning continuity due to the Covid-19 crisis?

2. Are instructors and students ready to use online learning as a result of the Covid-19 crisis?

3. What are the challenges and barriers to the adoption of online learning in Kuwait?

Educational institutions in developing countries have not fully optimised the benefits of e-learning. This may be attributed to the existence of barriers such as the lack of appropriate models and frameworks that hinder the effective integration of e- 
learning in educational systems $[8,9,10,7,11]$. This study proposes an integrated distance and blended learning model (DBLM) that can be used to help in the successful integration of e-learning platforms in Kuwait and other developing countries, focusing on e-learning delivery and instructors' readiness. Therefore, the principal objectives of the current study are to:

1. Develop an integrated distance and blended learning model (DBLM) which support successful e-learning in the light of identified critical factors and international practices.

2. Develop a flexible new model to evaluate educators' readiness and competence to operate within an e-learning system, which will be integrated with the proposed DBLM.

The remainder of this paper is organised as follows. Section 2 presents a literature review, followed in Section 3 by a description of the methodology adopted. Results and discussion are given in Section 4; Section 5 puts forward the proposed integrated DBLM. Section 6 concludes and suggests directions for future research.

\section{Literature Review}

Technological innovation in education allows the creation of open and flexible learning, facilitating blended and distance learning. However, educational institutions in developing countries have not fully optimised their use and benefits of online learning, which can be attributed to the existence of barriers affecting online learning acceptance [7, 11]. Selected studies presented in this section were carried out, pre-and post-Covid-19 pandemic, investigate online learning adoption and barriers associated with its implementation. Simultaneously, a considerable amount of literature proposed models and frameworks that help implement online learning. Overall, these studies emphasise the need to develop a model and provide a theoretical framework that can help improve distance learning implementation, mainly when face-to-face learning is impossible.

\subsection{Perceptions of online learning systems}

A considerable literature has emerged, addressing the adoption and perceptions of online learning. Due consideration should be given to the challenges posed by implementing e-learning platforms, particularly the potential barriers they pose. These have an important impact on acceptance, particularly during the Covid-19 crisis. A prepandemic review of the literature on known obstacles to online learning, including infrastructure, user skills, time, and poor communication, along with proposed solutions, was conducted by Ref. [12]. Another study [13] responded to the ban on faceto-face education by investigating online learning barriers among 3,670 medical students in the Philippines. Based on findings from an online questionnaire, barriers were categorised as institutional, technological, individual, domestic, and community, while the most frequent difficulties cited by respondents were adjusting to the new 
learning style, working from home, and inadequate educator-student communication. These findings complement those of Ref. [14], whose respondents frequently cited the barriers of lack of interaction with patients $(70 \%)$ and technical problems with ICT devices $(54 \%)$.

The research conducted by Ref. [15] examined the perceptions of international higher education (HE) students in China and found that while most accepted the implementation of e-learning programs, they were aware that a high cost involved this mode of educational delivery. The survey conducted on 416 university students by Ref. [16] showed most respondents have a positive perception of mobile learning. The study revealed that m-learning helped to recover the study gap during the Covid-19 time. Another survey of 1,045 Indonesian HE students conducted by Re. [17] indicated that $(40.3 \%)$ were generally satisfied with the shift to e-learning in response to the pandemic due to its flexibility and financial efficiency; however, $(53.7 \%)$ of respondents also mentioned frustration caused by network problems. Similarly, Ref. [14] surveyed 804 Polish medical students whose courses had been disrupted by online learning transfer due to the pandemic. The study reported that the advantages of elearning included the possibility of studying at home $(69 \%)$, accessibility of online materials $(69 \%)$, and learning anytime/anywhere $(64 \%)$. Hence, perceptions indicate a general acceptance of the shift to online learning. However, studies such as Ref. [18] reported social implications related to difficulties with access to technological devices, and Ref. [19] addressed challenges around implementation and internet access, as well as unease about financial issues.

\subsection{Online learning models and frameworks}

Technology-enhanced learning (TEL) can either be used as part of classroom activities (blended learning) or enable remote access if distance learning approaches are preferred [20]. An increasing amount of research has proposed online and distance learning models and frameworks addressing technological, social, and management challenges. Among recent frameworks, some focus on educators' most relevant issues, such as designing and creating instructional materials and how best to sustain online learning communities [21, 22, 23]. Others address matters including educator readiness [24, 10, 9], e-learning delivery [8, 22], learning environment [25, 26, 27], distance and blended learning [28, 29, 30], mobile learning [31, 32, 16, 33], and smart classroom [20]. An integrated e-learning model was proposed by Ref. [34] to identify organisational priorities, instructors' roles, learners' needs, and the learning environment as crucial factors in effectively enabling integrated e-learning. The study conducted by Ref. [29] specified Critical Success Factors (CSF) in online distance learning within higher education through a literature review and data analysis, from which they categorised five CSF: Institutional management; Learning environment; Instructional design; Service support; and Course evaluation.

The abrupt shift to distance and blended learning in developing countries, due to the current Covid-19 pandemic, urged Ref. [28] to propose a framework for teacher professional development focusing on factors such as instructor's emotion and drive, which has impacted their professional duties. Peer education and flipped learning are 
the two teaching approaches proposed by Ref. [27] during the Covid-19 pandemic in the United Kingdom. These techniques promote learning to occur outside the classroom using video learning materials created by the instructor. The proposed technique's main aim is to offer instructors modules to maximise student involvement and learning. Furthermore, in Poland, Ref. [30] proposed a modified blended learning technique that involved synchronous and asynchronous teaching techniques during the Covid-19 lockdown. This technique focuses on engineering education, highly dependent on practical exercises, experiments, and laboratory practices.

The implementation of any system of e-learning requires a reconfiguring and updating of educational institutions in terms of the technological readiness of both educators and students, as readiness is key to online acceptance. This process can be problematic. Both parties must have the competence to transfer or receive learning from a traditional to an online environment. An instructional competency framework developed by Ref. [10] aiming at ensuring instructors complete six specific types of elearning competencies. Other scholars have also addressed instructor readiness, including Ref. [35], who introduced Faculty Readiness Model to Teach Online (FRTO), derived from theoretical models. Another example is Ref. [36], who developed a 33item Readiness to teach online (RTTO) Scale, which addresses five categories: student engagement, technology support, course development, assessment, and evaluation criteria.

\section{Methodology}

Undertaking a review of the recent literature addressing how Covid-19 has impacted education worldwide will elucidate factors in the feasibility and success of adopting e-learning as a response to institutions' closure. A review was carried out of two literature streams: the first addressing the impact of the Covid-19 pandemic on education globally and the second addressing models and frameworks for e-learning implementation. Those mentioned above were conducted to set educational delivery changes following educational institutions' closure and indicate best e-learning implementation practices. The most recent publications were preferred. There has been little quantitative analysis to understand online learning's various perceptions due to banning face-to-face teaching. Therefore, a framework was developed, and data were gathered via a questionnaire designed to elicit educators' and students' perceptions of e-learning and the factors which impact its adoption.

\subsection{Framework development}

The framework developed for this research aimed to investigate educators' and students' perceptions of e-learning acceptance to determine the critical factors and challenges that impact its acceptance and adoption during the Covid-19 crisis. The identified factors and challenges may explain the success or failure of e-learning system adoption. The framework consists of 7 steps based on systems thinking precepts $[37,38]$. 
1. Boundary \& Stakeholders Definition.

2. Primary Acceptance Factors Extraction (literature).

3. Contextual Acceptance Factors Extraction (environment).

4. Factors-Questionnaire Transformation.

5. Administering the survey and gathering data.

6. Analysis \& Recommendations.

7. Proposed Integrated Model.

The first step is to identify the system in focus (Kuwaiti educational institutions) and define its boundary and principal stakeholders (educators and students). The second step consists of the literature review referenced in Section 2, namely works addressing the impact of the Covid-19 pandemic on education globally and models and frameworks for e-learning implementation. This review identifies the dimensions required to investigate the acceptance of e-learning. The third step requires identifying contextual factors affecting e-learning acceptance by both groups of stakeholders; hence, factors indicated in the literature are embedded in real-life occurrences in the environment under investigation. In this case, the identified acceptance dimensions are set against Kuwaiti officials, educators, students, and parents' opinions. After that, a table is drawn up, presenting identified dimensions with references to the literature from which they are extracted. The fourth step transforms the identified factors into questionnaire items to assess the reliability and possible validity of the survey instrument, while the fifth step involves administering the survey and collecting the data. The sixth step comprises statistical data analysis and recommendations, and in the seventh and last proposes the most efficient models for e-learning implementation.

\subsection{Study sample}

The sample was recruited from educators and students attending a range of private and public-sector educational institutions in Kuwait. Responses were gathered at twotime points: the pilot study and the main study. A total of 4,024 respondents answered all survey items. A gender and institutional category breakdown of the sample is given in Table 1.

Table 1. Characteristics of the study sample

\begin{tabular}{|l|l|c|c|}
\hline & & Frequency & \% \\
\hline \multirow{2}{*}{ Gender } & Male & 864 & 21.5 \\
\cline { 2 - 4 } & Female & 3,160 & 78.5 \\
\hline \multirow{2}{*}{ Category } & Student & 2,902 & 72.1 \\
\cline { 2 - 4 } & Instructor & 1,122 & 27.9 \\
\hline \multirow{2}{*}{ Institution type } & Government & 2,980 & 74.1 \\
\cline { 2 - 4 } & Private & 1,044 & 25.9 \\
\hline
\end{tabular}




\subsection{Data collection instrument}

The instrument for data collection was a questionnaire designed using phases 2 and 3 of the framework. Phase 2 extracts primary acceptance factors from the literature, and several previous studies influenced the outcome [39, 15, 36, 19]. In addition, contextual acceptance factors represent phase 3 [40, 41, 42]. Factors were divided into two dimensions: perception of online learning and barriers of online learning adoption in response to Covid-19. Table 2 shows each dimension and its link to the literature.

Table 2. Shaping the questionnaire (two dimensions)

\begin{tabular}{|l|l|l|}
\hline \multicolumn{1}{|c|}{ Dimension } & \multicolumn{1}{|c|}{ References from the literature } & $\begin{array}{l}\text { References from } \\
\text { the environment }\end{array}$ \\
\hline Perception of online learning & {$[14,32,15,43,30,28,44,31]$} & {$[40,41,42]$} \\
\hline Challenges and Barriers \& readiness & {$[14,12,45,35,36]$} & {$[40,41,42]$} \\
\hline
\end{tabular}

The questionnaire was developed with 21 items divided into two parts: the first consisted of three items gathering demographic data while the second consisted of 18 questions to be rated on a 3-point Likert-scale where 1=disagree, 2=neutral, and $3=$ agree. A pilot study was conducted to evaluate the instrument's suitability and effectiveness and verify the initial findings. A Cronbach's Alpha of 0.901 indicates reliability and generalizability to the primary study sample. The questionnaire was then randomly distributed by email and social media platforms, where a significant number of respondents took part in the online survey. Out of them, a total of 4,024 (educators and students) responses were found valid for data analysis. The collected data were then analysed quantitatively by using SPSS.

\subsection{Data analysis}

Descriptive statistics (frequency, percentage, mean, and standard deviation) were used to analyse the data sufficient for this study. The researchers used descriptive statistics because they are easy to understand and interpret, which is valuable for this research.

\section{$4 \quad$ Results and Discussions}

This section presents and discusses survey findings, emphasising factors and challenges impacting e-learning adoption during the Covid-19 pandemic.

\subsection{Online learning perceptions in response to the Covid-19 crisis in Kuwait}

Findings of perceptions of e-learning in response to Covid-19 are presented in Table 3. Across seven of the nine items, the mean value is close to, or slightly higher, than 2.0. The exceptions are Item 4 (lack of user skills), which elicited a neutral response with a mean value of 1.98. Item 7 (e-learning is an acceptable alternative to 
traditional laboratory experiments) produced a mean value of 1.95. A mean value of 2.10 for Item 1 (the use of e-learning is an appropriate solution to resume studying as a result of the Covid-19 crisis) suggests slight agreement among respondents. In general, the mean values indicate moderate agreement among educators and students that e-learning is an appropriate solution for educational needs during the Covid-19 crisis. When Kuwaiti authorities decided that e-learning would be used for the remainder of the academic year, it triggered considerable debate. The former Minister of education believes that e-learning was the best option in the circumstances and its advantages outweighed its disadvantages [41]. Moreover, 111 Kuwait University faculty signed a petition requesting that teaching be continued throughout the semester through elearning, stating that learning continuity was vital [42].

Table 3. E-learning acceptance in response to Covid-19

\begin{tabular}{|c|c|c|c|c|c|c|c|c|c|}
\hline \multirow[b]{2}{*}{ No. } & \multirow[b]{2}{*}{ Questions } & \multicolumn{2}{|c|}{ Disagree } & \multicolumn{2}{|c|}{ Neutral } & \multicolumn{2}{|c|}{ Agree } & \multirow[b]{2}{*}{ Mean } & \multirow[b]{2}{*}{$S D$} \\
\hline & & Freq. & $\%$ & Freq. & $\%$ & Freq. & $\%$ & & \\
\hline 1 & $\begin{array}{l}\text { The use of e-learning is an appropriate } \\
\text { solution to resume studying as a result } \\
\text { of the Covid- } 19 \text { crisis. }\end{array}$ & 1,175 & 29.2 & 1,267 & 31.5 & 1,582 & 39.3 & 2.10 & 0.822 \\
\hline 2 & $\begin{array}{l}\text { Adopting e-learning as a response to the } \\
\text { Covid-19 crisis does not serve the } \\
\text { educational process. }\end{array}$ & 1,127 & 28.0 & 1,253 & 31.1 & 1,644 & 40.9 & 2.13 & 0.820 \\
\hline 3 & $\begin{array}{l}\text { Adopting e-learning, in general, does } \\
\text { not serve the educational process even } \\
\text { after the end Covid- } 19 \text { crisis. }\end{array}$ & 1,167 & 29.0 & 1,085 & 27.0 & 1,772 & 44.0 & 2.15 & 0.841 \\
\hline 4 & $\begin{array}{l}\text { Lack of skills of using e-learning is a } \\
\text { reason why it is difficult to implement } \\
\text { considering the Covid- } 19 \text { crisis. }\end{array}$ & 1,517 & 37.7 & 1,062 & 26.4 & 1,445 & 35.9 & 1.98 & 0.858 \\
\hline 5 & $\begin{array}{l}\text { With e-learning, the student is more } \\
\text { flexible in learning, and learning can } \\
\text { take place anytime, anywhere. }\end{array}$ & 1,010 & 25.1 & 928 & 23.1 & 2,086 & 51.8 & 2.27 & 0.835 \\
\hline 6 & $\begin{array}{l}\text { E-learning is suitable for theoretical } \\
\text { courses. }\end{array}$ & 748 & 18.6 & 1,134 & 28.2 & 2,142 & 53.2 & 2.35 & 0.774 \\
\hline 7 & $\begin{array}{l}\text { E-learning is an acceptable alternative } \\
\text { to traditional laboratory experiments. }\end{array}$ & 1,343 & 33.4 & 1,548 & 38.5 & 1,133 & 28.2 & 1.95 & 0.783 \\
\hline 8 & $\begin{array}{l}\text { I prefer live video chat (synchronous) } \\
\text { with the instructor and the students. }\end{array}$ & 1,233 & 30.6 & 788 & 19.6 & 2,003 & 49.8 & 2.19 & 0.876 \\
\hline 9 & $\begin{array}{l}\text { I prefer reviewing video of the course } \\
\text { learning material (Asynchronous) of the } \\
\text { professor through platforms (such as } \\
\text { YouTube) at any time. }\end{array}$ & 867 & 21.5 & 873 & 21.7 & 2,284 & 56.8 & 2.35 & 0.812 \\
\hline
\end{tabular}

The mean value of 2.35 for Item 6 suggests a perception among respondents that elearning is suitable for theoretical courses, while that of 1.95 for Item 7 indicates that where laboratory-based classes are concerned, respondents are less sure of its effectiveness. Reference [40] echoed these findings, indicating that many Kuwaiti educators believe e-learning can be useful with theoretical subjects but less so with laboratory-based ones and exploratory learning, as the necessary technological conditions are difficult to create. However, multiple numerous virtual laboratories and applica- 
tions such as Ref. [46] has recorded the value of virtual laboratories as a means for students to practice experiments in disciplines such as science and engineering. Also, Ref. [47] recently studied students taking a lab-based optometry course and found that they accepted e-learning because they had a high level of technological skills. Hence, despite the diversity of opinion in Kuwait concerning the effectiveness of e-learning in scientific, engineering, and medical programs, several studies indicate that it can indeed be used for practical and laboratory learning [32].

Technological advance has enabled the development of open and flexible learning tools which foster engagement and collaboration [26], and advance computational thinking (CT), and develop students coding skills [48]. Since the ban on face-to-face learning was introduced in response to the spread of Covid-19, some educators have preferred to use asynchronous learning (video anytime, anywhere), while others have chosen to teach through real-time video (synchronous learning). Mean values of 2.19 and 2.35 for Items 8 and 9 suggest that synchronous learning is considered less effective by students than asynchronous learning. However, it should also be borne in mind that not all e-learning strategies are appropriate for students. Studies such as $[49,48]$ show that age, grade level, and disability should all be considered when choosing delivery modalities.

\subsection{Challenges and barriers to the adoption of e-learning}

Before education is moved online, it is vital to consider educational institutions' readiness, including educators and students [50]. An assessment must be made of whether educators are prepared to teach and collaborate online. Educators should possess the necessary skills to operate in the new environment, including digitising content, delivering it on an online platform, using an LMS, and evaluating students' progress. When e-learning is to be introduced very quickly, as in Covid-19 circumstances, it can be challenging to ensure both groups of stakeholders are ready and prepared. Table 4 presents the items designed to elicit respondents' perceptions of readiness, technology infrastructure, e-content, management, and social issues.

The mean value of 2.65 for Item 10 indicates agreement that both educators and students require training if they are to use e-learning effectively, while Item 11, with a mean value of 2.42 , suggests that respondents believe they are ready to learn the necessary skills. Our analysis indicates that both groups of stakeholders require upskilling if they are to use e-learning tools competently; however, the mean value of 1.73 for Item 12 also suggests that institutions are not providing the necessary upskilling programs

Multiple scholars in Kuwait have stated that there are challenges to the transfer to e-learning, including the fact that some members of both stakeholder groups may lack experience and knowledge of using the necessary equipment and navigating an online environment [42]. Some have opined that the use of e-learning in response to the crisis in public-sector educational institutions, in particular, will be problematic as neither educators nor students have the necessary skills [40]. Overall, the findings shown in Table 4 indicate an adequate level of readiness among educators and students for e-learning while also suggesting that both groups need some upskilling, 
particularly in software management, which should be promoted and enabled by their institutions. Among the challenges to schools, colleges, and universities globally undergoing the rapid switch from traditional to e-learning is a lack of strategic planning, infrastructure, high-quality electronic educational content, technological, and mobility [42]. However, according to Ref. [51], many mobile-based educational applications were not designed and developed to encourage young students to use technology to promote optimal development.

Table 4. Challenges and barriers to the adoption of e-learning

\begin{tabular}{|c|c|c|c|c|c|c|c|c|c|}
\hline \multirow{2}{*}{ No. } & \multirow[b]{2}{*}{ Questions } & \multicolumn{2}{|c|}{ Disagree } & \multicolumn{2}{|c|}{ Neutral } & \multicolumn{2}{|c|}{ Agree } & \multirow[b]{2}{*}{ Mean } & \multirow[b]{2}{*}{$S D$} \\
\hline & & Freq. & $\%$ & Freq. & $\%$ & Freq. & $\%$ & & \\
\hline 1 & $\begin{array}{l}\text { The use of e-learning requires the } \\
\text { training of instructors and stu- } \\
\text { dents to be able to use it effective- } \\
\text { ly. }\end{array}$ & 341 & 8.5 & 715 & 17.8 & 2,968 & 73.8 & 2.65 & 0.629 \\
\hline 2 & $\begin{array}{l}\text { I am ready to learn the skills that } \\
\text { help me to use e-learning. }\end{array}$ & 794 & 19.7 & 754 & 18.7 & 2,476 & 61.5 & 2.42 & 0.799 \\
\hline 3 & $\begin{array}{l}\text { My (school, college, university) } \\
\text { provides proper training courses } \\
\text { for using e-learning. }\end{array}$ & 2,063 & 51.3 & 990 & 24.6 & 971 & 24.1 & 1.73 & 0.825 \\
\hline 4 & $\begin{array}{l}\text { I see that we have a suitable infra- } \\
\text { structure (hardware-software - } \\
\text { networks) that contributes to the } \\
\text { success of e-learning. }\end{array}$ & 1,268 & 31.5 & 1,183 & 29.4 & 1,573 & 39.1 & 2.08 & 0.837 \\
\hline 5 & $\begin{array}{l}\text { Various digital e-learning re- } \\
\text { sources are covering our curricu- } \\
\text { lum. }\end{array}$ & 1,446 & 35.9 & 1,465 & 36.4 & 1,113 & 27.7 & 1.92 & 0.793 \\
\hline 6 & $\begin{array}{l}\text { One of the downsides of e- } \\
\text { learning under the Covid- } 19 \text { crisis } \\
\text { is the lack of confidence in the } \\
\text { test results. }\end{array}$ & 1,992 & 49.5 & 1,245 & 30.9 & 787 & 19.6 & 1.70 & 0.775 \\
\hline 7 & $\begin{array}{l}\text { Giving more scores on exercises } \\
\text { and activities and less on exams } \\
\text { when using e-learning helps in a } \\
\text { better assessment of student per- } \\
\text { formance. }\end{array}$ & 690 & 17.1 & 952 & 23.7 & 2,382 & 59.2 & 2.42 & 0.766 \\
\hline 8 & $\begin{array}{l}\text { There is encouragement and } \\
\text { motivation from (my school, my } \\
\text { college, my university) to use e- } \\
\text { learning. }\end{array}$ & 1,607 & 39.9 & 1,345 & 33.4 & 1,072 & 26.6 & 1.87 & 0.805 \\
\hline 9 & $\begin{array}{l}\text { The conservative Kuwaiti society } \\
\text { plays a role in not accepting e- } \\
\text { learning. }\end{array}$ & 1,369 & 34.0 & 1,295 & 32.2 & 1,360 & 33.8 & 2.00 & 0.824 \\
\hline
\end{tabular}

A mean value of 2.08 for Item 13 indicates educators and students believe the necessary infrastructure for successful e-learning in Kuwait is currently lacking. Similarly, a mean value of 1.92 for Item 14 indicates a lack of clarity around whether digital learning resources which can support e-learning are in place. Many respondents be- 
lieve that e-learning facilitates misconduct, including cheating, as indicated by the mean value of 1.6 for Item 15, concerning lack of confidence in test results during elearning implemented in response to the Covid-19 crisis. Reference [52] identifies motivation as a critical factor in creating an effective e-learning environment; however, the mean value of 1.87 for Item 17 suggests a lack of motivation among educators and students. Furthermore, the mean value of Item 18, 2.00, indicates respondents were split in their opinion of whether Kuwait's conservative culture would impact elearning acceptance.

Taken overall, the mean values indicate a low level of satisfaction among both stakeholder groups concerning the infrastructure, resources, preparation, and motivation required for e-learning to be effective. Moreover, responses to Item 19 suggest a particular concern among respondents about the validity of online examination and evaluation results. As Ref. [53] observe, many institutions have decided to cancel or postpone examinations given the concern around validity expressed by educators, students, and parents. It should, however, be noted that technological means to discourage cheating in online tests have been devised, including video surveillance, timed quizzes, random questions, biometrics, and other authentication tools [25].

\section{$5 \quad$ An Integrated Distance and Blended Learning Model (DBLM)}

Certain social and cultural factors must be considered in creating scientific content for distance or blended learning in Kuwait and the wider Arab world. Learning styles and environments in Kuwait and the other Gulf states lag behind many other countries [54]. In order to ensure effective distance and blended learning, a model must be devised which equips both educators and students with 21 st-century modes of learning, including self-learning, critical thinking, problem-solving, and creativity. This necessity poses a considerable challenge. The integrated model proposed in this paper is designed to facilitate the adoption and implementation of e-learning during the Covid19 pandemic, succeeded by classroom learning when it ends. The model's principal objective is to enable educators to create smaller, more flexible environments in which content is delivered. The internal and external dimensions which underpin the proposed model include virtual/smart classrooms, distance/blended learning methodology, e-content development, educators' capability and maturity, management, social and cultural change, regulation, and equipping students with 21 st-century learning skills. Educational Quality Assurance (EQA) is vital in that it focuses on ongoing improvement during each phase and level of the learning process to ensure that the desired learning outcomes are reached.

The proposed DBLM, depicted in Figure 1, offered a conceptual framework for implementing distance and blended learning in Kuwait. The framework takes account of the survey findings presented in Section 4 and insights derived from the literature review and success factors identified by various educational institutions. The learning environments are represented as the e-learning used during the pandemic, and secondly, blended learning for when the pandemic ends. All distance and blended learning 
models comprise the three components illustrated here: e-content development, elearning teachers' capability, and EQA.

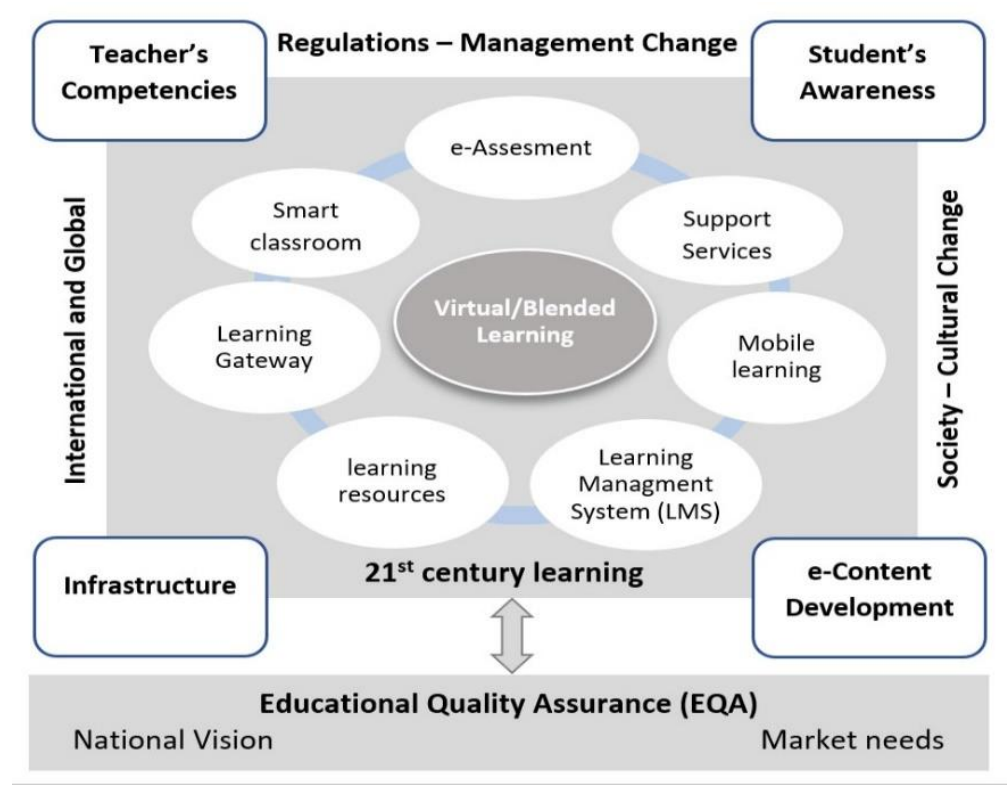

Fig. 1. Integrated distance and blended learning model (DBLM)

An effective distance learning system brings together and manages all elements within the infrastructure, from computer networks through ICTs to smart classrooms. The LMS is a software application designed to provide learning resources, automate administrative processes, and monitor and report program delivery. Username, sometimes password-protected, access to the learning gateway offers a single portal to the LMS and all the collaboration tools it encompasses for all stakeholders, whether students, parents, educators, or administrators. The learning gateway principally manages the e-learning systems, hosts interactive e-content, integrates the administrative and education systems, and offers a collaborative space for stakeholders to interact [55].

Technical, management, social, cultural, and other considerations all impact the success and effectiveness of a DBLM, as all these functions must interact harmoniously if they are to form an integrated whole. Moreover, the implementation must take account of the best interests of all stakeholders and society more widely. Suppose distance education is to be accepted within the community. In that case, resistance to change must be addressed, and there must be trust that the new learning environment will be adequately regulated and fairly. Stakeholders must believe that the new system makes a genuine contribution to education development and leverages technologies to achieve both educational and social objectives. Twenty-first-century learning, which is a fundamental element of DBLM, extends traditional learning modalities and, at its most effective, facilitates a more thoughtful, thorough learning journey, leaving students ready for the challenges of lifelong learning and contribution. The new type of 
learning is characterised by anytime, anywhere access, applies design thinking to complexities, and brings entrepreneurialism into education to identify new opportunities to add value continually.

\section{$5.1 \quad$ e-Content development}

The success of e-learning implementation depends on a high degree of a proper understanding of how e-content is developed, particularly incorporating dynamic and interactive multimedia [56]. Although a wide range of technologies has emerged to facilitate the development of e-learning content, instructional designers should continue to be led by research-based pedagogical principles rather than technological possibilities [22]. E-content design and development must comply with international design standards to ensure quality [8] so Arab e-Universities can add to the stock of knowledge in the Arab world. Moreover, distance learning courses must be designed so that their content meets student expectations of quality and tools.

\subsection{Educator capabilities in e-learning}

According to [57], enhancing instructors' ability and creating a positive attitude concerning the use of technology in teaching and learning requires the existence of an appropriate environment for their development. Further challenges to the effective implementation of an integrated DBLM lie in educators' competence to use the technological tools required by this learning environment and administrators' readiness to ensure that both content and delivery environment meet the necessary quality standards. The survey findings presented in Section 4, which address students' and educators' perceptions of e-learning readiness, underline the key role of educators' readiness to act in the new online environment and address the behavioural and social implications of the abrupt change in learning delivery mode due to the pandemic.

The authors propose the e-learning teacher capability maturity model (eTCMM), presented in Figure 2, an extended version of the Instructional Competency Model of Ref. [10]. Our model has added behavioural, social, and cultural dimensions due to their importance within the recent shift to e-learning. The eTCMM demonstrates how an educator can gradually improve her competence levels. 


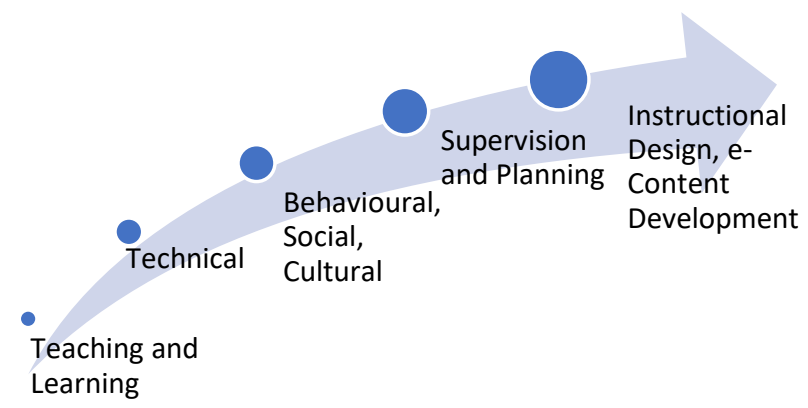

Fig. 2. e-Learning Teacher Capability Maturity Model (e-TCMM)

\section{- Teaching and learning}

An educator's personality directly influences her ability to manage within an elearning environment, including her readiness and ability to acquire the knowledge and skills required to master new teaching and learning strategies. An educator should be able to interact effectively with her students and manipulate the curriculum both inside and outside a classroom. This requires her to have the skills, perceptiveness, and emotional intelligence to understand each student's potential, current ability, and cultural background to choose which teaching methods best meet their needs.

\section{- Technical and applications}

Within an e-learning environment, the educator must have the practical expertise required to use technological tools and software applications to explain the curriculum and deliver course content. Hence, a certain technical skill level is necessary to efficiently and creatively use computers, ICTs, collaboration tools, software programs, and an LMS.

\section{- Behavioural, social, and cultural}

Since the educator's basic role within an e-learning environment is to facilitate the learning process, she must interact with students in multiple ways to foster positive behaviours. Doing so requires her to have the behavioural and social skills necessary to keep the learning environment positive and healthy.

\section{- Supervision and planning}

Planning and supervision competencies include, among other things, setting out the overall objectives of an e-curriculum and how they should be met. It also involves determining how a curriculum is best delivered, lesson planning for a range of learner types, and identifying the best tools to give and elicit feedback. Hence, educators must be ready to acquire a suite of planning and supervision competencies. 


\section{- Instructional design and e-content development}

High-level competency is required to be able to design and develop online digital content. This is generally the preserve of software experts and trained instructional designers aiming to meet certain specific pedagogical objectives and usability standards, including cultural ones. However, for e-learning to be successfully implemented, educators should have a broad understanding of how e-content is developed. Instructors can make a valuable contribution by identifying desired learning outcomes and best teaching methods by integrating learning styles in the design of educational interfaces [49].

\subsection{Educational Quality Assurance (EQA)}

Given that e-learning takes place in an intensely technological environment, it is vital to have an EQA system in place. Educational standards determine the levels of achievement and outcomes required from the whole educational process and the strategies to achieve these and other objectives [58]. As EQAs have been widely recognised as a CSF in any education system, multiple countries have undertaken various initiatives to implement and enforce them. Moreover, EQAs are known to be useful tools within schools' management and administration processes which is another reason for their careful selection and implementation [59]. However, in the unprecedented circumstances of the global Covid-19 pandemic, as educational delivery has transferred across the world from traditional to distance models, EQA has acquired a new dimension.

Quality control within e-learning delivery poses a significant challenge, while applying it to blended learning adds another layer of complexity. An EQA must assess and analyse feedback, then feed it back into the system to improve learning and teaching processes and content. Within e-learning, this last step mainly entails ensuring smooth integration [10]. Hence, it is necessary to discuss what type of quality control can best monitor and improve online content and teaching in a blended environment.

\section{Conclusion and Future Research}

This research has aimed to identify the critical factors impacting e-learning acceptance in response to the ban on traditional classroom instruction introduced to stem the spread of the Covid-19 virus in Kuwait. A quantitative method was applied, whereby questionnaires were administered to educators and students from a range of Kuwaiti educational institutions. Our findings indicate that respondents tend to support e-learning and consider its principal advantages: first, providing flexible learning and fostering the habit among learners of consulting a range of sources to find information. However, findings also indicate that technological skills development is needed if respondents benefit from e-learning fully. Social, technical, and institutional factors were all identified as impacting e-learning adoption. Social factors include confidence, lack of awareness of the potential offered by this education method, and 
how to use the tools and resources that support it. Language problems may also arise, as too few resources are available in Arabic. Technological factors include infrastructure, LMS, technical support, network bandwidth, communication, and collaboration tools, while institutional ones include strategic planning, management support, encouragement, motivation, and training.

This study's objectives were met by reviewing the methods used in prior research to analyse the current situation's requirements, issues impacting acceptance, and barriers to e-learning. Undertaking a review of the recent literature addressing how Covid-19 has affected education worldwide will elucidate factors in the feasibility and success of adopting e-learning as a response to institutions' closure. A review was carried out of two literature streams: the first addressing the impact of the Covid-19 pandemic on education globally and the second addressing models and frameworks for e-learning implementation. There has been little quantitative analysis to understand online learning's various perceptions due to banning face-to-face teaching. Based on this review, data analysis of the survey study conducted in Kuwait, and following international practices, an integrated Distance and Blended Learning Model (DBLM) was proposed to consider Kuwait's educational systems as a robust foundation for the rollout of e-learning. Furthermore, given the critical importance of instructor readiness in successfully implementing e-learning, the authors proposed an elearning teacher capability maturity model (eTCMM).

The current crisis is a suitable moment to explore the potential of online learning and actively identify benefits and pressure points to ensure greater readiness and resilience in the face of any future crisis. Hence, Kuwaiti educational authorities should strive to design, activate, and implement e-learning platforms and overcome the barriers to acceptance. In particular, plans should be made to deal with worst-case scenarios in a way that will ensure resilience, cost-effectiveness, and stability. In this research, the perceptions of the instructors and students cannot be fully adopted. This is a limitation because e-learning has not been fully embedded within the Kuwaiti educational systems even though with initiatives of utilising e-learning in some educational institutions.

It is suggested that future research should include study samples from other GCC countries, for example, Saudi Arabia, Oman, Bahrain, Qatar, and the UAE. These countries share social and cultural characteristics to determine whether they show differences in rates and patterns of e-learning acceptance.

\section{$7 \quad$ Acknowledgements}

The current research was funded by the Kuwait Foundation for the Advancement of Sciences under project code: "CORONA PROP 95".

\section{$8 \quad$ References}

[1] UNESCO, "Distance learning solutions," 2020. [Online]. Available: https://en.unesco.org/ covid19/educationresponse/solutions. [Accessed 16 April 2020]. 
[2] J. Lau, B. Yang and D. Rudrani, "Will the coronavirus make online educa-tion go viral?," By Joyce Lau, Bin Yang and Rudrani Dasgupta March 2020. [Online]. Available: https://www.timeshighereducation.com/features/will-coronavirus-make-online-educationgo-viral. [Accessed 14 April 2020].

[3] W. Horton, "E-learning by design," John Wiley \& Sons, 2011.

[4] S. AL-Sharhan, A. Al-Hunaiyan and W. Gueaieb, "Success factors for an efficient blended learning. In Proceedings of the 10th IASTED Interna-tional Conference on Internet And Multimedia Systems And Applica-tions, pages 77-82," 2006.

[5] S. Papadakis, M. Kalogiannakis, E. Sifaki and N. Vidakis, "Access moo-dle using smart mobile phones. A case study in a Greek University," in In-teractivity, Game Creation, Design, Learning, and Innovation, Springer, Cham, 2017, pp. 376-385. https://doi.org/10. 1007/978-3-319-76908-0_36

[6] M. Lieberman, "Coronavirus Prompting E-Learning Strategies," 3 March 2020. [Online]. Available:https://www.edweek.org/ew/articles/2020/03/04/coronavirus-prompting-elearning-strategies.html. [Accessed 15 April 2020].

[7] M. AlKharang, Factors that Influence the Adoption of e-Learning An Empirical Study in Kuwait. Phd. Thesis, London: Brunel University Lon-don, 2014.

[8] B. Adeoye, "The Era of Digital Technology in Teaching and Learning in Nigeria Educational Institutions. 2020," in The Roles of Technology and Globalization in Educational Transformation, Hershey, PA: IGI Global, 2020. http://doi:10.4018/978-1-5225-9746-9, 2020.

[9] G. Gay, "An assessment of online instructor e-learning readiness before, during, and after course delivery.," Journal of Computer in Higher Educa-tion, 2016(28), p. 199-220, 2016. https://doi.org/10.1007/s12528-016-9115-Z

[10] A. Al-Hunaiyyan, S. Al-Sharhan and H. Al-Sharrah, "A New Instructional Competency Model: Towards an Effective E-Learning System and Envi-ronment," International Journal of Information Technology \& Computer Science (IJITCS), vol. 5, pp. 94-103, 2012. https://doi.org/10.1109/icdim.2012.6360142

[11] G. Kituyi and R. Kyeyune, "An Analysis of E-learning Information Sys-tem Adoption in Ugandan Universities: Case of Makerere University Business School," Information Technology Research Journal Vol .2(1), April 2012, pp. 1-7, 2012.

[12] D. O'Doherty, M. Dromey and J. Lougheed, "Barriers and solutions to online learning in medical education - an integrative review," BMC Medi-cal Education18, 130 (2018). 2018. https://doi.org/10.1186/s12909-018-1240-0

[13] R. e. a. Baticulon, "Barriers to online learning in the time of COVID-19: A national survey of medical students in the Philippines," 2020. [Online]. Available: https://www.medrxiv. org/content/10.1101/2020.07.16.20155747v2

[14] M. Bączek, M. Zagańczyk-Bączek, M. Szpringer, A. Jaroszyński and B. WożakowskaKapłon, "Students' perception of online learning during the COVID-19 pandemic: a survey study of Polish medical students," 2020. [Online]. Available: https://www.researchsquare. com/article/rs-41178/v1. https://doi.org/10.21203/rs.3.rs-41178/v1

[15] J. Demuyakor, "Coronavirus (COVID-19) and Online Learning in Higher Institutions of Education: A Survey of the Perceptions of Ghanaian International Students in China," Online Journal of Communication and Media Technologies, 10(3), 2020. https://doi.org/ $10.29333 / \mathrm{ojcmt} / 8286$

[16] B. Biswas, S. Roy and F. Roy, "Students Perception of Mobile Learning during COVID19 in Bangladesh: University Student Perspective," Aquademia, 4(2), ep20023, 2020. https://doi.org/10.29333/aquademia/8443 
[17] K. Yamin, "Mixed response but online classes to stay post COVID-19," 14 May 2020. [Online]. Available: https://www.universityworldnews.com/post.php?story=20200514121 749886. [Accessed 25 July 2020].

[18] M. Drolia, E. Sifaki, S. Papadakis and M. Kalogiannakis, “An Overview of Mobile Learning for Refugee Students: Juxtaposing Refugee Needs with Mobile Applications' Characteristics," Challenges, 11(2),31, pp. 1-14, 2020. https://doi.org/10.3390/challe11020031

[19] M. Girik Allo, "Is the online learning good in the midst of Covid-19 Pan-demic? The case of EFL learners. 10," Jurnal Sinestesia, Vol. 10, No. 1, April 2020, pp. 1-10, 2020.

[20] S. Al-Sharhan, "Smart classrooms in the context of technology-enhanced learning (TEL) environment: A holistic Approach," in Transforming Edu-cation in the Gulf Region Emerging Learning technologies and Innova-tive Pedagogy for the 21st Century, London, Taylor \& Francis, 2016.

[21] N. Al-Huwail, S. Al-Sharhan and A. Al-Hunaiyyan, "Learning Design for a Successful Blended E-learning Environment: Cultural Dimensions. Jour-nal of Computer Science," INFOCOMP Volume 6 - No. 4, pp. 60-69, 2007.

[22] M. Hamdi and T. Hamtini, "Designing an Effective e-Content Develop-ment Framework for the Enhancement of Learning Programming," Inter-national Journal of Emerging Technologies in Learning (iJET). Vol 11, No 04 (2016), pp. 131-141, 2016. https://doi.org/ 10.3991/ijet.v11i04.5574

[23] R. Alhajri, S. Counsell and X. Liu, "Accommodating individual differ-ences in web based instruction (WBI) and implementation," in International Conference on e-Business (ICEB), 1-9, 2013.

[24] S. Almutairy, T. Davies and W. Dimitriadi, "The Readiness of Applying M-Learning among Saudi Arabian Students at Higher Education," Inter-national Journal of Interactive Mobile Technologies iJIM, vol. 9, no. 3, pp. 33-36, 2015. https://doi.org/10.3991 lijim.v9i3.4423

[25] C. Meilleur, "Countering cheating in eLearning," 8 Feb 2018. [Online]. Available: https://knowledgeone.ca/countering-cheating-elearning/. [Ac-cessed 1 May 2020].

[26] J. Zhang, D. Burgos and S. Dawson, "Advancing open, flexible and dis-tance learning through learning analytics,", Distance Education, 40:3, pp. 303-308, 2019. https://doi. org/10.1080/01587919.2019.1656151

[27] C. Nerantzi, "The use of peer instruction and flipped learning to support flexible blended learning during and after the COVID-19 Pandemic," In-ternational Journal of Management and Applied Research, 7(2), pp. 184-195., 2020. https://doi.org/10.18646/2056.72.20-013

[28] B. Lockee, "Shifting digital, shifting context:(re) considering teacher pro-fessional development for online and blended learning in the COVID-19 era," Educational Technology Research and Development, 1-4., 2020. https://doi.org/10.1007/s11423-020-09836-8

[29] B. Cheawjindakarn, P. Suwannatthachote and A. Theeraroungchaisri, "Critical Success Factors for Online Distance Learning in Higher Educa-tion: A Review of the Literature," in Creative Education 2012, 2012. https://doi.org/10.4236/ce.2012.38b014

[30] A. Ożadowicz, "Modified Blended Learning in Engineering Higher Educa-tion during the COVID-19 Lockdown-Building Automation Courses Case Study," Education Sciences, 10 (10), 292, 2020. https://doi.org/10.3390/educsci10100292

[31] S. Papadakis, M. Kalogiannakis, E. Sifaki and N. Vidakis, "Evaluating Moodle use via Smart Mobile Phones. A case study in a Greek Universi-ty," EAI Endorsed Transactions on Creative Technologies, 5(16), 2018. https://doi.org/10.4108/eai.10-4-2018.156382

[32] A. Al-hunaiyyan, S. Al-Sharhan and R. Alhajri, "Instructors Age and Gender Differences in the Acceptance of Mobile Learning," International Journal of Interactive Mobile Technologies (iJIM). Vol. 11, No. 4, 2017. https://doi.org/10.3991/ijim.v11i4.6185 
[33] L. Alfarani, "Influences on the Adoption of Mobile Learning in Saudi Women Teachers in Higher Education," International Journal of Interac-tive Mobile Technologies. iJIM, vol. 9, no. 2, pp. 58-62, 2015. https://doi.org/10.3991/ijim.v9i2.4411

[34] D. Newton and A. Ellis, "A model for e-learning integration," Honolulu, Hawaii, 2006.

[35] F. Martin, C. Wang, A. Jokiaho and B. May, "Examining Faculty Readi-ness to Teach Online: A Comparison of US and German Educators," Eu-ropean Journal of Open, Distance and e-Learning Vol. 22 / No. 1, pp. 53-69, 2019. https://doi.org/10.2478/eurodl2019-0004

[36] A. Chi, Development of the readiness to teach online scale, University of Denver, 2015.

[37] A. Elias and R. Cavana, "Stakeholder Analysis for Systems Thinking and Modelling," 2011. [Online]. Available: https://www.researchgate.net/publication/253711729.

[38] S. Raza, A. Siddiqui and C. Standing, "Exploring Systemic Problems in IS Adoption Using Critical Systems Heuristics," Systemic Practice and Ac-tion Research, 32. p. 125-153, 2018. https://doi.org/10.1007/s11213-018-9467-6

[39] A. Al-Hunaiyyan, R. Alhajri and S. Al-Sharhan, "Perceptions and chal-lenges of mobile learning in Kuwait," Journal of King Saud University - Computer and Information Sciences Volume 30, Issue 2, pp. 279-289, 2018. https://doi.org/10.1016/j.jksuci.2016.12.001

[40] Academia, "Discussion Forum: Online learning in Light of COVID-19," 29 March 2020. [Online]. Available: http://dlvr.it/RSnh0X.

[41] Al-Anbaa, "Benefits of Distance Learning," 1 April 2020. [Online]. Avail-able: https://alanba.com.kw/959659/?utm source=whatsapp.

[42] Anbaa, "Opinions of Faculty Members of Online Learning as a reponse to COVID-19 Crises," 10 April 2020. [Online]. Available: https://alanba.com.kw/961334/?utm_source= whatsapp.

[43] M. Shahabadia and M. Uplaneb, "Synchronous and asynchronous e-learning styles and academic," Procedia - Social and Behavioral Sciences 176, p. 129-138, 2015.

[44] R. Chatterjee, "Exploring the relationship between attitude towards col-laborative learning and sense of community among college students in online learning environments: a correlational study," Iowa State Universi-ty, Ames, Iowa, 2015. https://doi.org/10.31274/etd$\underline{180810-3862}$

[45] L. Parvin, "Barriers in Implementing E-Learning in Hormozgan University of Medical Sciences," Global Journal of Health Science. 2016 Jul; 8(7), p. 83-92, 2016.

[46] N. Andriotis, "What are Virtual Laboratories and how do they work in eLearning?," 12 Sep 2016. [Online]. Available: https://www.talentlms.com/blog/virtual-laboratorieselearning/. [Accessed 3 May 2020].

[47] M. Acosta, A. Sisley, J. Ross, I. Brailsford and A. Bhargav, “Acosta ML, Sisley A, Ross J, Brailsford I, Bhargava A, et al. (2018) Student ac-ceptance of e-learning methods in the laboratory class in Optometry," PLOS ONE 13(12), 2018. https://doi.org/10.1371/journal. pone.0209004

[48] S. Papadakis, "Apps to Promote Computational Thinking Concepts and Coding Skills in Children of Preschool and Pre-Primary School Age," in Mobile Learning Applications in Early Childhood Education, IGI Global, 2020, pp. 101-121. https://doi.org/10.4018/978-17998-1486-3.ch006

[49] R. Alhajri and A. Al-Hunaiyyan, "Integrating Learning Style in the Design of Educational Interfaces," ACSIJ Advances in Computer Science: an In-ternational Journal, Vol. 5, Issue 1, No.19, January 2016. ISSN : 2322-5157, 2016.

[50] CoSN, "COVID-19 Response: Preparing to Take School Online," 1 March 2020. [Online]. Available: https://www.cosn.org/sites/default/files/COVID-19\%20Member\%20Exclusive $\underline{0 . p d f}$. [Accessed 15 April 2020]. 
[51] M. Kalogiannakis and S. Papadakis, "An evaluation of Greek educational Android apps for preschoolers.," in Proceedings of the 12th Conference of the European Science Education Research Association (ES ERA), Re-search, Practice and Collaboration in Science Education, Dublin, 2017.

[52] M. Hartnett, "The Importance of Motivation in Online Learning," in Mo-tivation in Online Education, Singapore, Springer, 2016.

[53] S. Burgess and H. Sievertsen, "Schools, skills, and learning: The impact of COVID-19 on education,” 01 April 2020. [Online]. Available: https://voxeu.org/article/impact-covid-19education. [Accessed 20 April 2020].

[54] A. Al-Hunaiyyan, R. Alhajri, A. Al-Zayed and B. Alraqqas, "Towards an Effective Distance Learning Model: Implementation Framework for Arab Universities," International Journal of Computer Application. Volume 6, Issue 5, 2016.

[55] U. Maldonado, G. Khan, J. Moon and J. Rho, "E-learning motivation and educational portal acceptance in developing countries," Online Infor-mation Review. 35, pp. 66-85, 2011. https://doi.org/10.1108/14684521111113597

[56] R. Clark and R. Mayer, E-learning and the science of instruction: Proven guidelines for consumers and designers of multimedia learning, John Wiley \& Sons, 2011. https://doi. org/10.1002/9781118255971

[57] M. Kalogiannakis and S. Papadakis, "The dual form of further education of educators in ICT: technological and pedagogical training," in Proceed-ings of the 8th International Conference On Computer Based Learning in Science, Heraklion V. 30, 2007, pp. 265-276.

[58] M. Cheng, "Quality as transformation: Educational metamorphosis," Quality in Higher Education, 20 -3, p. 272-289, 2014. https://doi.org/10.1080/13538322.2014.978135

[59] S. Saeed, "Impact of Quality Assurance on Academic Performance," In-ternational Journal of Social Sciences \& Educational Studies, 5. http://dx.doi.org/10.23918/ijsses.v5i1p178, 2018.

\section{Authors}

Dr. Ahmed Al-Hunaiyyan is a faculty member in the Department of Computer and Information Systems at the College of Business Studies, PAAET, Kuwait. He earned his Ph.D. in the field of Computer Science, specialising in multimedia interface design, from Hertfordshire University, UK. He participated in various academic institutions, Al-Ain University, U.A.E., Waubonsie College, USA, Hertfordshire University, UK, Public Authority for Applied Education and Training (PAAET), Kuwait, Gulf University for Science and Technology (GUST), and Kuwait University. Dr. Al-Hunaiyyan's research interests include multimedia in education; mobile learning; eLearning; human-computer interaction; software design; usability; cultural issues related to information technology. Email: aa.alhunaiyyan@ paaet.edu.kw

Dr. Rana Alhajri is a faculty member in the Computer Science Department at the Higher Institute of Telecommunication and Navigation, PAAET, Kuwait. She earned her Ph.D. in the field of Computer Science from Brunel University, United Kingdom. Dr. Alhajri's research interests include multimedia in education; mobile learning; eLearning; human-computer interaction; software design; usability; cultural issues related to information technology, and Individual differences in Designing Web Based Instructions. Email: rana_alhajri@yahoo.com 
Dr. Bimba Andrew Thomas: He received a bachelor's degree in electrical and electronics engineering in 2006, a master's degree in Computer Science (Artificial Intelligence) in 2014, and a Ph.D. in Computer Science (Artificial Intelligence), College of Information Technology University of Malaya. His research interests include a cognitive knowledge base, natural language processing, artificial intelligence in education, machine learning, and computer-human interaction. Email: drbimbaphd@gmail.com

Article submitted 2021-01-19. Resubmitted 2021-03-08. Final acceptance 2021-03-18. Final version published as submitted by the authors. 